\title{
Concept of reducing cost of mining thin low-power uranium veins with using narrow web mining machine.
}

\author{
Alekseev Oleg Nikolaevich \\ director, LLC Mechanical-Repair Plant \\ Russia \\ $\underline{\text { AlekseevON@ppgho.ru }}$
}

\author{
Akchurin Zuffar Firanusovich \\ chief engineer, Directorate on Support of \\ Production, PJSC PPGHO \\ Russia \\ AkchurinZF@ppgho.ru
}

\begin{abstract}
In the article, the experience of low-power uranium ore bodies working off is considered. The practical experience of low-power ore bodies working off with the use of load-haul-dumpers (LHD) of the middle class of PD-2E type or Toro150 at the mines of PJSC PPGHO is accumulated.
\end{abstract}

Keywords-narrow web, load-haul-dumper, dilution, analysis, landinds, low-power veins.

\section{INTRODUCTION}

In the $60 \mathrm{~s}$ of the 20th century in Russia, the largest uranium field "Streltsovsky Ore Field" was explored (SOF), including about 20 uranium fields that provided within nearly 50 years stable functioning of the only and one of the world's largest in Russia underground mining and chemical complex of production and processing of uranium ores.

However, due to the intensive exploitation of fields of the Streltsovsky ore field in the XX century at the present stage, there was a trend toward reducing the uranium content in ores exploited fields.

Currently, a large part of the uranium ore, located in SOF, is the spent ore. Landings of natural uranium are thin lowpower uraniums, whose share in the total volume of excavation is more than $70 \%$. This type of ore basin is characterized by a highly complex structure and morphology, the irregularity of the ore, the changing power of tectonic disturbance and the heterogeneity of roaches. The basic system of development veins of uranium ore bodies in the PJSC PPGHO (horizontal layers of hardening bookmark) in connection with the deterioration of mountain-geological and mining conditions becomes unprofitable due to the large volume of preparatory-threaded and backfilling operations $[1,2]$. One of the promising areas to increase the costeffective marginal deposit of a complex structure of the uranium bodies is the development and implementation of narrow web load-haul-dump machines (LHD).

\section{AVAILABLE TECHNOLOGY}

At present, for mining thin low-power uranium veins, load-haul-dumpers (LHD) of the middle class are used. The machine with electric drive PD-2E is created by the design engineers of the mechanical-repair plant (RMZ) PJSC PPGHO and is made of components of the Russian manufacturers [5].

However, used for the delivery of mined rock to ore chutes, machine PD-2E does not mitigate the dilution when mining thin ore bodies. Used narrow web machines of foreign production L130D, (French company "Aramain"), LH201D (Finnish company "SANDVIK TAMROCK") on the mines of PJSC PPGHO has revealed positive and negative sides of their operation. A significant disadvantage for the load-haul-dump machines with the diesel drive is the increased requirements for mine ventilation due to the formation of exhaust from a running diesel engine. This drawback in underground conditions is of particular importance due to the current capacity of the mine workings in the air, the cross section of which is set based on the location of mining and transport equipment, communications and necessary clearances. A flaw in the construction of the machine LH201D is the knuckle joint of the frame, going out of the system when operating in mines. For L130D, the weak link is the hydraulic system of the working body, which does not provide the required cycle parameters of mined rock shipment. In the process of operation of VSD, it is necessary to use only those brand of fuel, oils and lubricants, and coolant that are recommended by the manufacturer. It also creates maintenance problems and causes additional costs, which are about $10 \%$ of the cost of the machine. Analysis of information from open sources on the cost of foreign mining equipment showed that for the development of low-power uranium veins of the Streltsy ore field, a domestic narrow web loading and delivery machine is necessary, which is inexpensive and easy to operate [4].

In conditions of harsh international economic sanctions in relation to the development of strategic industries of Russia, PJSC PPGHO in the framework of the state program of import substitution has put the task of creating a domestic narrow web loading and hauling machines for mining thin deposit 
uranium before the staff REP. To substantiate the design parameters of the new PDM, a comparative analysis of the narrow web loading and delivery equipment manufactured by foreign companies was carried out. As the main indicators, they considered scoop capacity, machine width, type of drive. The analysis performed by the authors on the basis of the technical characteristics of LHD is presented in table1.

TABLE I. TECHNICAL CHARACTERISTICS OF FOREIGN LOAD-HAUL-DUMPERS

\begin{tabular}{|c|c|c|c|c|c|c|}
\hline \multirow[t]{2}{*}{ Parameter } & \multirow[t]{3}{*}{ Unit } & \multicolumn{5}{|c|}{ Manufacturer and model } \\
\hline & & \multicolumn{2}{|c|}{$\begin{array}{l}\text { Lida (KNR) } \\
\text { CУ- } 0,75\end{array}$} & \multicolumn{2}{|c|}{$\begin{array}{l}\text { SANDVIK } \\
\text { (Finland) } \\
\text { LH201D LH201E }\end{array}$} & \multirow{2}{*}{$\begin{array}{l}\text { Aramain (France) } \\
\text { L130D } \\
\text { diesel }\end{array}$} \\
\hline Type of drive & & $\begin{array}{l}\text { diese } \\
1\end{array}$ & electric & $\begin{array}{l}\text { dies } \\
\text { el }\end{array}$ & electric & \\
\hline Engine power & $\mathrm{kVt}$ & 42 & 37 & 33 & 30 & 40 \\
\hline \multicolumn{7}{|l|}{ Geometrical parameter: } \\
\hline - length & $\mathrm{mm}$ & 5710 & 5710 & $\begin{array}{l}460 \\
0\end{array}$ & 4840 & 5345 \\
\hline - width & $\mathrm{mm}$ & 1250 & 1250 & $\begin{array}{l}105 \\
0\end{array}$ & 1050 & 1040 \\
\hline - height & $\mathrm{mm}$ & 1900 & 1900 & $\begin{array}{l}210 \\
0\end{array}$ & 2040 & 1990 \\
\hline Weight & $\mathrm{kg}$ & 6500 & 6500 & $\begin{array}{l}370 \\
0\end{array}$ & 3850 & 4700 \\
\hline Scoop capacity & $\mathrm{m}^{3}$ & 0,75 & 0,75 & 0,54 & 0,54 & 0,6 \\
\hline Length electric cable & $\mathrm{m}$ & - & 120 & - & 80 & - \\
\hline
\end{tabular}

\section{METHOD OF SOLUTION}

A series of industrial experiments was carried out to solve the problem of creating a narrow web PDM. Analysis of the physical modelling of the movement of roach at the site determined the design of the LHD and its quantitative specifications [6]. In order to improve the technology of the development system "Horizontal layers with hardening tab", it is planned to maximize the use of domestic narrow web machines with the technical characteristics specified in table 2 [3].

In 2018, RMZ of PJSC PPGHO made PDM PD-1E (Figure 1), which has successfully passed the factory end-ofline test. According to the results of industrial experiments, the knuckle joint of the frame of a new design, characterized by reliability from the design of the company "Aramain", increased the capacity of the cable - rell drum to $190 \mathrm{~m}$, provides protection of the entrance to the cab PDM, ensuring the safety of the operator's feet from the collapse cutter break. Instead of belt transmission, machine LH201E, PD-1E includes a pump drive gear box, which allowed one to increase the power of rotational torque.
TABLE II. TECHNICAL CHARACTERISTICS OF THE LOAD-HAUL-DUMPERS MACHINE FOR MINING THIN LOW-POWER URANIUM VEINS

\begin{tabular}{|l|c|c|}
\hline Name of parameter & Unit & Parameter value \\
\hline Type of electric motor & $\begin{array}{c}\text { AIR225M4 } \\
45 / 1500\end{array}$ \\
\hline Engine power & $\mathrm{kVt}$ & 45 \\
\hline Geometrical parameter: & $\mathrm{mm}$ & 5525 \\
\hline - length & $\mathrm{mm}$ & 1055 \\
\hline - width & $\mathrm{mm}$ & 1990 \\
\hline - height & $\mathrm{m}^{3}$ & 0,6 \\
\hline Scoop capacity & $\mathrm{kg}$ & 4700 \\
\hline Weight: & $\mathrm{kg}$ & 6200 \\
\hline - empty & $\mathrm{m} / \mathrm{s}$ & 1,6 \\
\hline - laden & $\mathrm{degree}$ & 15 \\
\hline Driving performance: & $\mathrm{m}$ & \\
\hline $\begin{array}{l}\text { - speed of movement of the } \\
\text { car }\end{array}$ & $\mathrm{t} / \mathrm{h}$ & 190 \\
\hline $\begin{array}{l}\text { - the maximum climbing } \\
\text { grade }\end{array}$ & & \\
\hline Length electric cable & & \\
\hline $\begin{array}{l}\text { Technical performance at a } \\
\text { length delivery of } 100 \mathrm{~m}\end{array}$ & & \\
\hline
\end{tabular}




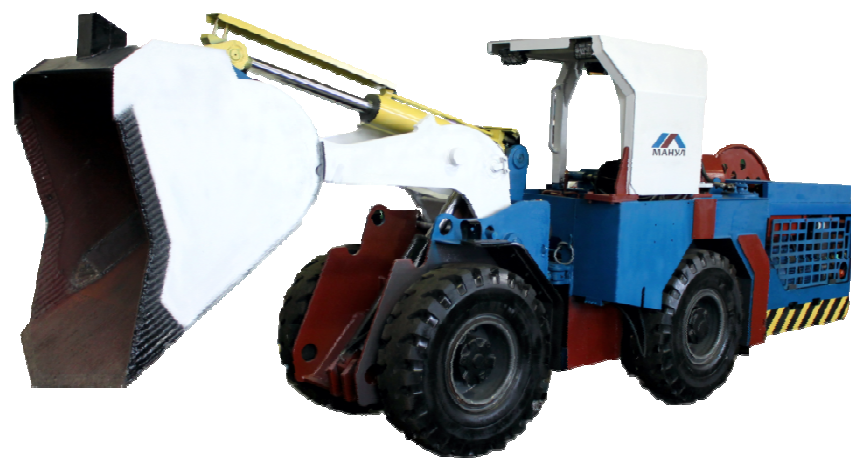

Fig. 1. The load-haul-dumpers machine PD-1E
In the hydraulic circuit, in contrast, foreign machinery, installed 2 gear-type pump, which allowed one to divide the flow of oil into the working body and the body of turning motion. As a result, the reliability of the machine during operation has increased.

Delivery of the muck pile ore in mining is carried out by means of load-haul-dumpers machines, the width of which determines the maximum value of the contamination of ore extraction [1].

The overall width of the machine $-1055 \mathrm{~mm}$ allows the layer at bench mining of thin deposit uranium veins to reduce the width of wide dass from $3.5 \mathrm{~m}$ to $2 \mathrm{~m}$ and reduce the contamination of ore to $20 \%$. This is graphically illustrated in figure 2 .

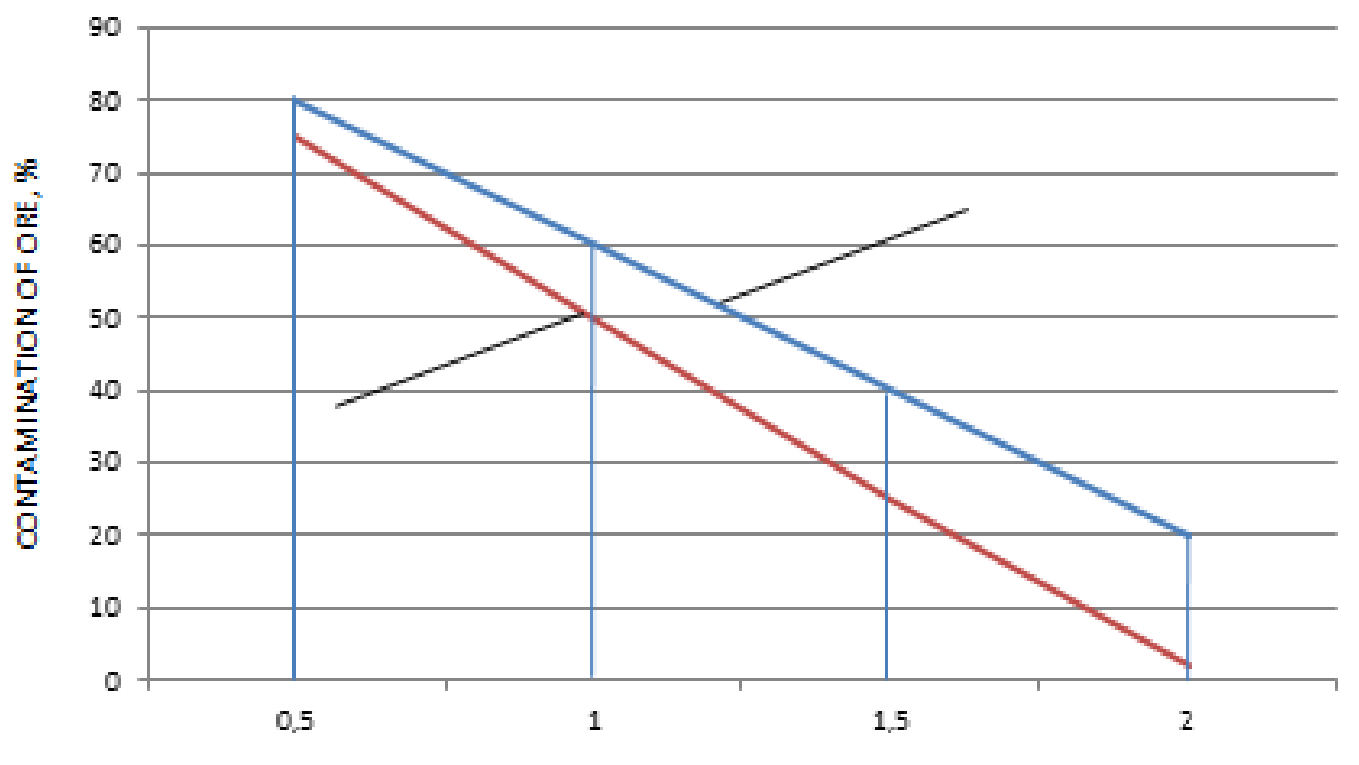

POWERM.

Fig. 2. The dependence of the contamination of ore on ore width and LHD type. 1 - LHD PD-1E, 2 - LHD PD-2E

Based on the results of industrial tests machine PD-1E on mine N1, PJSC PPGHO, a decision will be made on the finalization of the PDM, the elimination of shortcomings and setting in serial production. The development of the production of a new narrow web PDM PD - 1E will reduce the dilution, provide the required contamination of ore, reduce capital costs for the acquisition and maintenance-for the repair and maintenance of the machine.

\section{CONCLUSIONS}

Due to high percent of uranium ores dilution, big losses of metal and high maintenance expenses, the need to find new ways of prime cost decrease of natural uranium extraction has appeared. Scientific research works have shown that one of the perspective directions is development and deployment of the domestic narrow web load-haul-dumper - PD-1E with the electric drive.

The dependence of uranium ores dilution on ore bodies' power has been stated as a result of field trials. The constructive and technological shortcomings of LHD, elimination of which will allow one to increase the LHD mobility, its technical reliability and safety of operator's work during the collapse of sided balmstones are revealed. The use of the development system "Horizontal layers with hardening backfilling" with the use of domestic narrow web load-hauldumper PD-1E will allow one to reduce ores dilution and prime cost of mining by $15-20 \%$. 


\section{References}

[1] V.G. Ivanov, V.I. Kultyshev, etc. Development optimization of hard structural uranium fields. - M.: Mining Book publishing house, 2007.

[2] V.I. Kultyshev, A.A. Reshetnikov, etc. KSUKP GDP. The system of horizontal layers development with hardening backfilling. STP 0106120-2000, Krasnokamensk: OJSC PPGHO, 2001.

[3] Specifications "Load-haul-dumper PD-1E" TU 3143-069-076210602011, Krasnokamensk: JSC PPGHO, 2011.
[4] O.N. Alekseev, V.A. Ovseychuk, "Development of the domestic cheap electrohydraulic load-haul-dumper for low-power ore bodies working off," Bulletin of the Chita State University, Vol. 2, 2009, pp. 39 - 43.

[5] B.B. Kolesayev, "Formation and development of the Priargunsk production mining and chemical association," M: Mining Journal, Vol. 8, 2008, pp. 12 - 17.

[6] V.R. Imenitov, Processes of underground mining operations when developing ore fields. Manual for higher education institutions, 3rd prod., revised and added, M: Nedra, 1984. 